\title{
Performance Improvement in the Spanish Local Government: A Proposal for Internal Control in Social Care Services
}

\author{
Carolina Pontones Rosa ${ }^{1}$, Rosario Pérez Morote ${ }^{1} \&$ Clara Isabel Muñoz Colomina ${ }^{2}$ \\ ${ }^{1}$ Faculty of Management and Economy, University of Castilla la Mancha, Albacete, Spain \\ ${ }^{2}$ Faculty of Management and Economy, Complutense University, Madrid, Spain \\ Correspondence: Carolina Pontones Rosa, Faculty of Management and Economy, University of Castilla la \\ Mancha, Albacete, Spain. E-mail: Carolina.Pontones@uclm.es
}

Received: February 4, 2013

Accepted: March 4, 2013

Online Published: March 11, 2013

doi:10.5539/ibr.v6n4p10

URL: http://dx.doi.org/10.5539/ibr.v6n4p10

\begin{abstract}
Proper public management is not possible without the existence of internal control mechanisms that ensure reliability of the information for decision making. In Spanish local government this involves overcoming certain weaknesses detected for the internal control and audit function. Based on some of the results obtained by the authors through a survey over Spanish local government internal and external auditors, this work confirms the existence of consensus regarding the need to design and implement internal control mechanisms that assure reliable and useful information on performance and results. Upon this scenery, the paper puts forward a proposal for the development of the internal control, using the case of Homecare Services as a model. This system pursues to provide a useful tool for public managers, contributing to reduce the effects of the financial context over performance, as well as to facilitate cooperation with external audit.
\end{abstract}

Keywords: Spanish local government, social care services, survey, internal control system, performance indicators

\section{Introduction: Background and Approach to the Research Problem}

The relationship between performance measurement and management improvement is a matter of interest in the field of public services (Kravchuk et al., 1996; Helgason, 1997; Rubenstein, 2003).In Spain, the autonomy of local government contrasts with systems in other more centralized countries, such as the UK, where performance measures play a clearly defined role in national evaluation and control. The study of Torres et al (2011) found out that Spanish local governments are, at present, experimenting with different approaches to implementing performance measurement systems, influenced by their environmental context and the lack of a central government top-down approach. Progress is being made in this regard and a stronger approach to internal control and performance audits is observed (García, 2007; Conferencia de Presidentes de los ÓrganosAutonómicos de Control Externo, 2006; Torres, 2002).

Although there is still a long way to go, the development of the strategic administration in Spanish public sector has meant a greater focus on internal control systems. In particular, there is an interest for extending the practice of performance or value for money audits, as well as for complementing the traditional budgetary and accounting techniques with new reporting tools, such as performance indicators (García, 2007).

The presented work delves into the analysis of the processes of control and outcomes measurement. Applied to an entity, the internal control system is an integral process designed to address risks and provide reasonable assurance that, in pursuit of the entity's mission, the following general objectives are being achieved: executing orderly, ethical, economical, efficient and effective operations, fulfilling accountability obligations, complying with applicable laws and regulations and safeguarding resources against loss, misuse and damage (INTOSAI, 2004). This definition is comprehensive of the one issued by the Committee of Sponsoring Organizations of the Treadway Commission, COSO Report (Coopers \& Lybrand, 1997).

Internal control is also defined by the Spanish Technical Standards on Auditing (ICAC, 1991, standard 2.4.3) as the system comprising the organization plan and the set of methods and procedures that ensure that assets are properly protected, that the accounting records are reliable and the activity of the entity develops effectively and meets the guidelines set by the management. In order to reach its objectives, the internal control system uses a 
set of means, in particular: plans and programs, organization, methods and procedures and other mechanisms of control. To this, it should be added the system of internal audit, as a tool of revision (Christensen \& Yoshimi, 2003)

Management control involves, ultimately, the set of activities that integrate both the control and the planning process. It requires the design and implementation of a coherent set of indicators that facilitates the control of critical activities (Navarro, Ortiz \& Lopez, 2008). The evaluation, for its part, constitutes the final stage of the control process and consists of studying the most significant deviations to detect its causes and responsible, and also, to identify and select the possible alternatives that could correct these deviations, evaluating actions associated with each one of them (Byars, 1984).

The aims and components of the internal control system referred to are perfectly valid for local government in general, and for the department or area of social care services, in particular, given that the controls must be implemented in the various divisions, departments and bodies of the Authority (Barquero, 2008; Pallot, 2001).

In Spain, the Ley Reguladora de Bases de Régimen Local (LRBRL, 1985), in its article 136, sets out that the administrative body responsible for the inspection and the internal control of the financial and budgetary management in local government is the General Auditor -Intervención General- of each entity, which will develop this feature in its triple meaning: intervening, financial control and audit of efficacy or effectiveness. For its part, the TextoRefundido de la Ley de Reforma de Haciendas Locales (TRLRHL, 2004) provides the content and scope of such competencies.

The intervening function constitutes an internal control of legality and probity. This paper is not concerned with the analysis of this function and the problems that it presents in the Spanish local public arena, being the works of Biosca (2010) or Lazo (2008) available for consulting, among others. On the opposite, this paper leads to the study, within the internal auditor feature, of what Spanish regulations name "control of efficacy or effectiveness", as well as its connection with the so-called "financial control".

With regard to the former, the local government's internal auditor must carry out an effectiveness inspection which "shall be directed to check periodically the degree of fulfillment of the objectives, as well as the analysis of the cost of the activity and the performance of the services or investments" (article 221 of the TRLRHL).

On the other hand, as regards "financial control", it shall be directed to test the financial aspect of the local authorities' services, to inform about the adequate presentation of financial information, the compliance with the applying standards and guidelines, and the degree of efficiency and effectiveness in the achievement of the preset objectives. It shall be performed by audit procedures, in accordance with the public sector auditing standards, and its conclusions and observations will be gathered in a written report. The reports, together with the allegations made by the audited body, will be sent to the Full Board Council for consideration (article 220 of the TRLRHL).

The doctrine coincides in the lack of clarity in the Spanish legislation to define the content and scope of the financial and efficacy -or effectiveness- controls in local government. In the opinion of González (2008), the financial control is more related to financial audit, whereas surveillance of economic rationality and the results of performance is part of what the law calls effectiveness control.

Therefore, the exercise of an efficacy control by the internal auditor remains fundamental for management to adopt a focus for improvement. Unfortunately, there is not a set of procedures or a code of practice for its realization, and the Auditing Standards for the Public Sector to which Spanish legislation refers are insufficient to assure its practice, which leaves value for money inspection at the internal auditor's discretion (Viñas, 2003).

On the other hand, and leaving aside the distinction between the different types of control, there is an agreement about the importance for the internal control to be independent to prevent irregular performances and fraudulent handling of public resources, acting as a guarantee. In Spain, the lack of a homogeneous development of the statutory content of the roles and responsibilities attributed to the internal auditors, which separates their functions clearly from management, along with the legal gaps in matters such as the means at their disposal or the guarantees for their work, have as a result a limited impact of local government's internal control system. Often, the dependency of the internal auditor from the inspected body, on key elements such as part of their retributions, makes the quality and content of their work biased and undermined in its practical scope(Biosca, 2010).

Another question of relevance is related to the demand of a greater coordination between internal and external systems over local government. In this area, both LRBRL and TRLRHL (art. 115 y 223, respectively), point out that external control of the accounts and financial management of local authorities corresponds to the Court of Audit and, to some extent, to regional audit bodies. Together, the Audit of Court and the regional external audit 
bodies are called OCEX -Organismos de Control Externo-. Even though the budget regulations explicitly include value for money controls as part of the obligations and powers of the OCEX, and there exists a broad consensus on its appropriateness and need, in Spain it has dominated financial regularity and legality audit, performance inspection being still a challenge for OCEX, even more in local government.

Taking into account the above mentioned, collaboration and coordination between internal and external controls is considered as an effective mechanism for achieving a proper and comprehensive review of local management (Viñas, 2002). Besides, according to the rules governing the audit function, the review of the internal control system is compulsory for the auditor, should this examination act as a base for the decision on the approach to audit to take.In order to contribute to this purpose, the accounting system of the entity must be able to provide sufficient information as to the performance developed.

On the other hand, evolution of socio-demographic trends in Spain suggests there will be a significant growth of the demand for care services in the medium and long term (Díez, 1999; Gutiérrez, 2007). At the same time, the current economic situation creates the need to allocate greater resources to care services to cover emergency needs (Fernández et al., 2008). These factors, together with the complexities inherent to this branch of social welfare, make social services an interesting area of research, where public management must be subjected to far-reaching reforms. This paper is concerned with public management of social care services in Spanish local government.

Spanish local government is responsible for the provision of social care services, mainly primary care, when its population exceeds 20,000 inhabitants. At the same time, the competence in this matter lies with the correspondent Regional Government. In practice, many functions of regional responsibility are carried out with the cooperation of local authorities, which see how the volume of its activities and services are increased without a proportional increase of resources from the rest of the administrations. The existing funding model has been criticized for being unfair and for causing a permanent financial tension. There is a lack of correspondence between the financial instruments available, the potential revenue that can be generated and the volume of services provided (El Defensor del Pueblo del País Vasco, 2010).

The trends and reforms undertaken in UE countries in the field of social services have been analysed by Antonnen and Sipila (1996), Casado and Fantova (2007) and, with a more general approach, by Esping-Andersen (1990). In Spain, many are the authors who have studied the management process of social services in local government (Kelley, 1984; Fantova, 2008; Garau, 2005; García, 2005; Setién \& Sacanell, 2003; Subirats, 2007; FEMP, 2009).

The Spanish Association of Social Services Directors (2007) recommends issuing information on performance and results in the field of social care and making it available to the public. Similarly, the Spanish Federation of Municipalities and Provinces (FEMP, 2009) considers that the implantation of mechanisms for performance evaluation and measurement within local government contributes to enhance citizen's perception on public social services. This approach shows a strong link between performance measurement, value for money control, transparency and accountability (Boyne et al., 2002; Birkett, 1988; Brugue, 1996; Zafirovski, 2001).

Therefore, the future strategy of the Spanish public social services must address some challenges, being urgent the adoption of measures to maintain planned investments and services' quality. It is necessary to manage public expenditure in a more rigorous way, to review priorities, to streamline processes and optimize the use of resources. Ultimately, it is vital to examine the public offer through a cost-benefit analysis. In this regard, the implementation of internal and external control mechanisms can contribute to value for money improvement.

This research builds on the assumption that the problems affecting local government as a social services manager can be overcome through the application of reporting and control mechanisms. In particular, this paper highlights the benefits of implementing an effective control system within the management processes of social services.

\section{Goal and Objectives}

Considering the limitations exposed as to the current situation of the internal control in the Spanish local government, this paper aims to highlight the urgent need of reinforcing the role of internal auditors within Spanish local government, as regards the reporting on management and results. This is coupled with the need to clarify the hierarchical independence of this figure. The independence of internal auditors to exercise the internal control must be guaranteed in the imminent reform of Spanish local government. Therefore, a first objective of the study is to show the opinion of those responsible for the control of performance in Spanish local government, statutory internal and external auditors. Collaboration between them is considered key for the effectiveness of the control system. The convenience of introducing changes to empower their functions and the advantages of 
using reporting and control mechanisms are some of the matters addressed. In particular, performance indicators and self-assessments at public services' level are put forward as levers for improvement and cooperation between internal and external controllers.

On the other hand, growing on the high consensus detected through the empirical analysis, the paper offers a practical application of the theoretical issues analysed. To this end, a proposal for the design of an Internal Control System is applied to social services. It gives away a general guide including the planning function and the organization and procedures from where an information system is built. On those foundations, it proposes a set of control mechanisms crystallized in performance indicators, making up a balanced scorecard. The intention of this is to provide a useful tool for public managers, as well as to facilitate the cooperation with external control and raise transparency.

Homecare Services have been selected for this practical application, although the intent of the authors is to make the proposal extended to other social services. This selection is founded on its consideration as a basic and essential service within the Spanish public offer, together with its uniform implementation throughout the national territory (Note 1).

This practical application to Homecare Services attempts to provide a useful tool for public managers that facilitate cooperation with external control mechanisms. At the same time, it intends to help reducing the dramatic effects that the current financial situation is causing in the management of care services and other local public services (Note 2). This kind of practical application has been barely developed in Spanish public services and social care. The authors consider that public managers and auditors must be endowed with instruments to measure and report on performance in order to raise value for money and transparency.

\section{Methodology}

A number of hypotheses might derive from the research undertaken. In particular, regarding the limitations identified for the internal control function, the following two arise:

Hypothesis 1: It is necessary to define and clarify the responsibilities of the internal control function with regard to the generation of information on performance, as well as its hierarchical dependency within the entity.

Hypothesis 2: The internal auditor must review the information generated on the management and the results of public services' provision.

Besides, with the aim of supporting our proposal for an internal control system, another two hypotheses are put forward:

Hypothesis 3: Local government should undertake self-evaluations on its performance and results, contributing to assist in the work of external auditing.

Hypothesis 4: Local government should, through its internal control system, put in place compulsory indicators of economy, effectiveness and efficiency for each service.

In order to verify these hypotheses, the authors carried out an online survey in Spain, aimed at internal auditors General Auditors (Intervención General) and external auditors (OCEX) in Spanish local government. As mentioned before, these two groups are responsible for internal and external control both in terms of legality and performance, in accordance with Spanish local government regulations. The consideration of their opinion and their different views is core to understanding the impact of control processes over the outcomes studied. Regarding internal auditors, it is also of relevance to investigate the differences in opinion depending on the town administrated by the council to which the internal auditor belongs. The size of the town (number of inhabitants) is associated with the size of the local authority and the volume of resources available for control. This might mean different internal control systems depending on the size of the council.

The data collection period was April 2011 to January 2012. Prior to its launch, a pre-test was applied and the online platform used was validated by a group of experts from the faculty to which the authors are attached.

\subsection{Population and Sample}

In the case of internal auditors, the population considered was made up of those discharging their functions in Spanish municipalities from 20,000 inhabitants onwards. The establishment of a bottom limit at the level of 20,000 inhabitants is founded on the fact that that is the size determined by Spanish local regulations (LRBRL, art. 26) from which councils have to deliver social services in a compulsory way. At the same time, the authors considered that councils under that size would not have enough resources to accomplish an effective internal control on their performance, at least on the terms required by Spanish Law. 
As previously explained, the size of the population of internal auditors was determined by the number of Spanish councils exceeding 20,000 inhabitants, which amounted to 387 in 2010 (National Institute of statistics, INE). On the other hand it must be taken into account that this population was comprehensive of a wide variety of sizes in terms of inhabitants or population covered. The number of inhabitants is related to the volume of budget and resources available. This fact suggested dividing the population into different strata (see table 1), on an attempt to obtain more homogenous groups. Besides, this division by strata would allow exploring the diversity of perceptions of internal auditors belonging to councils of different size.

With regard to the sampling, due to the strata division commented, the technique of stratified sampling has been applied. A stratified sample is a probability sampling technique in which the researcher divides the entire target population into different subgroups, or strata, and then randomly selects the final subjects proportionally from the different strata. This type of sampling is used when the researcher wants to highlight specific subgroups within the population (García, 2005, pág. 7). For Sánchez Crespo (1976) this methodology is associated to a number of advantages such as gaining precision and keeping an equal probability of election for all units within the universe. According to it, the sample of internal auditors must reach the following levels in each stratum to be representative.

Table 1. Population and sample of internal auditors applying stratified sampling (No. of councils)

\begin{tabular}{lllllll}
\hline & $20,001-30,000$ & $30,001-50,000$ & $50,001-100,000$ & $100,001-500,000$ & Over 500,000 & TOTAL \\
\hline Population & 144 & 98 & 83 & 56 & 6 & 387 \\
Weigh of the strata & 0,37 & 0,25 & 0,21 & 0,14 & 0,02 & 1,00 \\
Samplerequired & 53 & 24 & 18 & 8 & 1 & 104 \\
\hline
\end{tabular}

After data collection, 109 responses from internal auditors were gathered (28.1\% of the population as a whole, representing 30 provinces out of the 50 existing). This sample was distributed by the defined strata as shown in table 2 .

Table 2. Sample of internal auditors distributed by the defined strata

\begin{tabular}{lll}
\hline Strata & Sample (\%) & No. respondents \\
\hline $20,001-30,000$ inhabitants & $48.6 \%$ & 53 \\
$30,001-50,000$ inhabitants & $22.0 \%$ & 24 \\
$50,001-100,000$ inhabitants & $17.4 \%$ & 19 \\
100,001-500,000 inhabitants & $7.3 \%$ & 8 \\
Over 500,000 inhabitants & $4.6 \%$ & 5 \\
\hline
\end{tabular}

The number of respondents for the collective "internal auditors" abides by the stratified sampling requirements explained in table 2, allowing us to consider it representative.

With regard to external auditors or OCEX members, the population is determined by the number of Statutory OCEX in Spain, which amounted to 14 at the end of 2011. The sampling was not probabilistic and conditioned by the possibility to contact and gain access to the opinions of the OCEX members. After data collection, responses from 15 OCEX members were obtained, representing six different OCEX (46\%) (see table 3).

Table 3. Members of OCEX sample

\begin{tabular}{l}
\hline OCEX \\
\hline Cámara de Cuentas de Andalucía \\
Sindicatura de Cuentas de Castilla-La Mancha \\
Sindicatura de Cuentas de Cataluña \\
Sindicatura de Comptes de les IllesBalears \\
Cámara de Comptos de Navarra \\
Tribunal Vasco de Cuentas Públicas \\
\hline
\end{tabular}

\subsection{Variables Identified}

The nominal variable "opinion" measures the level of acceptance of the respondents regarding the matters questioned. This variable adopted a likert scale from 0 to 4; "1" meaning total agreement; "2", agreement; "3", disagreement; "4", total disagreement; and "0", don't know/not answer.

Another nominal variable is the "collective" to which the respondent belongs. This may adopt two possible 
values "1" (internal auditors) and "2" (external auditors).

Finally, a third nominal variable can be identified: the "size of the council", which adopts values ranging from “1" (20,001-30,000 inhabitants), "2" (30,001-50,000), “3" (50,001-100,000), "4" (100,001-500,000) to "5" (over $500,000)$.

\subsection{Statisticals Applied}

The nature of the variables, qualitative and expressed in a nominal scale, suggested the application of non-parametric tests (Santos et al., 1999). The selection of a particular test depends on several factors, mainly the number of and the relationship between the samples. Considering this, the data collected was graphically represented through contingency tables (Vicéns \& Medina, 2005). These tables give away the opinions of both collectives as to each question, broken down into strata for the case of internal auditors.

Chi Square test was used to find out about the existence of independence between variables "collective" and "opinion". Besides, the size of the sample (under 150) recommended applying Correction for Continuity of Yates to the Chi Square statistical (Pérez, 2003). Independency is discarded when the asymptotic significance is under 0.05 , for a confidence level of $95 \%$.

Also, association coefficients $\mathrm{C}$ of Contingency and V of Cramer were calculated to assess the strength of the dependency between these two variables, but only for the case that Chi Square and Correction for Continuity of Yates were statistically significant (Note 3 ).

Finally, for the sample of internal auditors, Kruskall-Wallis H test was carried out to analyze the independence between the variables "size of the council" and "opinion". This non-parametric test is indicated to compare more than two independent subsamples (the five possible values for the variable "size of the council"). Its interpretation will depend on the statistical Chi Squared; for values under 0.05 , the hypothesis on equality of the population means will be not accepted.

The results of this questionnaire and the verification of the hypotheses will be addressed in the next section.

As regards the methodology followed for the practical application to homecare services of an internal control system, it consisted of a qualitative analysis (Coffey \& Atkinson, 2004; Morse, 2005; Hesse - Biber \& Leavy, 2006) of the existing regulations on social services at the national, regional and local level in Spain. At the Statelevel, Homecare Services delivery is affected by the national pact called Plan Concertado de Prestaciones Básicas en las Corporaciones Locales (1988), and the Ley de Promoción de la Autonomía Personal y Atención a las Personas en Situación de Dependencia (2006). However, given the constitutional competence of the autonomous communities in social care, the main legislative sources are the regional social services laws and their regulatory developments. At the same time, Homecare Services provision is a delegated power to local government where its population exceeds 20,000 residents, which means local level regulations applying to its delivery. The similarities found among normative and planning and organization documents consulted, allowed us to take the particular case of Castilla - La Mancha Autonomous Community as representative of the whole country as regards homecare services delivery.

\section{Analysis of the Results Obtained}

For the verification of the first of the raised hypotheses, the following question was included in the questionnaires:

Within local government, is it necessary to define and clarify the responsibilities of the internal control function with regard to the generation of information on performance and results, as well as its hierarchical dependency?

As reflected in table 4, the results allow us to confirm this hypothesis, given that more than $90 \%$ in all groups are in favor of a better definition for the internal control functions. In addition, $100 \%$ of the internal auditors, belonging to municipalities of more than 50,000 inhabitants, expressed prone to such a measure.

Table 4. Contingency table related to hypothesis 1

\begin{tabular}{llllll}
\hline & Totally agree & Agree & Disagree & DK/NA & Total \\
\hline $20,000-30,000$ pop. & $38.64 \%(17)$ & $52.27 \%(23)$ & $6.82 \%(3)$ & $2.27 \%(1)$ & $100.00 \%(44)$ \\
$30,001-50,000$ pop. & $50.00 \%(11)$ & $40.91 \%(9)$ & $9.09 \%(2)$ & $0.00 \%(0)$ & $100.00 \%(22)$ \\
$50,001-100,000$ pop. & $56.25 \%(9)$ & $43.75 \%(7)$ & $0.00 \%(0)$ & $0.00 \%(0)$ & $100.00 \%(16)$ \\
$100,001-500,000$ pop. & $37.50 \%(3)$ & $62.50 \%(5)$ & $0.00 \%(0)$ & $0.00 \%(0)$ & $100.00 \%(8)$ \\
$>500,000$ pop. & $40.00 \%(2)$ & $60.00 \%(3)$ & $0.00 \%(0)$ & $0.00 \%(0)$ & $100.00 \%(5)$ \\
OCEX & $38.46 \%(5)$ & $53.85 \%(7)$ & $7.69 \%(1)$ & $0.00 \%(0)$ & $100.00 \%(13)$ \\
\hline
\end{tabular}

Source: personal elaboration. 
When going deeper into the data, it can be observed that auditors and members of the OCEX are not different, in general, in their views to this idea. Independence between both factors is confirmed Ji-squared by Pearson (p-value 0.74 ) and Correction for Continuity by Yates (p-value 1).

On the other hand, if we consider solely the collective of internal auditors, Kruskal-Wallis H Test (p-value 0.69) reveals not significative, meaning that there are not differences in opinion to this subject between the samples for each of the five defined population strata.

As far as the second hypothesis is concerned, its contras used the next question within the questionnaires:

Should the review of the information generated on performance and results figure among the functions of the internal auditor?

Table no. 5 exposes the answers gathered by the surveys,showing a high level of support that exceeds $80 \%$ in all groups.

Table 5. Contingency table related to hypothesis 2

\begin{tabular}{|c|c|c|c|c|c|c|}
\hline & Totally agree & Agree & Disagree & Totally disagree & DK/NA & Total \\
\hline 20,000-30,000 pop. & $42.86 \%(15)$ & $45.71 \%(16)$ & $8.57 \%(3)$ & $0.00 \%(0)$ & $2.86 \%(1)$ & $100.0 \%(35)$ \\
\hline 30,001-50,000pop. & $37.50 \%(6)$ & $50.00 \%(8)$ & $6.25 \%(1)$ & $0.00 \%(0)$ & $6.25 \%(1)$ & $100.0 \%(16)$ \\
\hline 50,001-100,000 pop. & $60.00 \%(9)$ & $33.33 \%(5)$ & $6.67 \%(1)$ & $0.00 \%(0)$ & $0.00 \%(0)$ & $100.0 \%(15)$ \\
\hline $100,001-500,000$ pop. & $25.00 \%(2)$ & $62.50 \%(5)$ & $12.50 \%(1)$ & $0.00 \%(0)$ & $0.00 \%(0)$ & $100.0 \%(8)$ \\
\hline$>500,000$ pop. & $75.00 \%(3)$ & $25.00 \%(1)$ & $0.00 \%(0)$ & $0.00 \%(0)$ & $0.00 \%(0)$ & $100.0 \%(4)$ \\
\hline OCEX & $25.00 \%(3)$ & $66.67 \%(8)$ & $0.00 \%(0)$ & $8.33 \%(1)$ & $0.00 \%(0)$ & $100.0 \%(12)$ \\
\hline
\end{tabular}

Source: personal elaboration.

Likewise, the independency tests applied confirm that the opinion of this issue does not vary, in statistical terms, with the collective considered -internal or exterla auditor-, since p-value is zero for both Ji-squared and Correction for Contuinity.) Also, Kruskal-Wallis H Test (p-value 0.36) indicates that there are not differences in opinion to this subject among internal auditors depending on the population covered by their local authority.

Acceptance of the first two hypotheses can corroborate the theses maintained in this work, whereby the internal auditor must take an active role in the configuration of the system of internal control of collections, making effective what the Spanish law calls "control of efficacy".

With regard to the convenience of developing self-assessments and indicators, and aiming at supporting our proposal for an internal control system, the following questions were included in the questionnaires for the contrast of the third and fourth hypotheses:

Question: Should local government develop self-evaluations on its performance and results, contributing this way to assist in the work of external auditing?

Table number 6 reflects the high acceptance to this proposal, which becomes full in member of OCEX and internal auditors of municipalities of more than 100,000 inhabitants.

Table 6. Contingency table related to hypothesis 3

\begin{tabular}{|c|c|c|c|c|c|c|}
\hline & Totally agree & Agree & Disagree & Totally disagree & DK/NA & Total \\
\hline $20,000-30,000$ pop. & $34.29 \%(12)$ & $51.43 \%(18)$ & $8.57 \%(3)$ & $2.86 \%(1)$ & $2.86 \%(1)$ & $100.0 \%(35)$ \\
\hline 30,001-50,000pop. & $31.25 \%(5)$ & $43.75 \%(7)$ & $18.75 \%(3)$ & $0.00 \%(0)$ & $6.25 \%(1)$ & $100.0 \%(16)$ \\
\hline 50,001-100,000 pop. & $42.86 \%(6)$ & $50.00 \%(7)$ & $7.14 \%(1)$ & $0.00 \%(0)$ & $0.00 \%(0)$ & $100.0 \%(14)$ \\
\hline $100,001-500,000$ pop. & $37.50 \%(3)$ & $62.50 \%(5)$ & $0.00 \%(0)$ & $0.00 \%(0)$ & $0.00 \%(0)$ & $100.0 \%(8)$ \\
\hline$>500,000$ pop. & $50.00 \%(2)$ & $50.00 \%(2)$ & $0.00 \%(0)$ & $0.00 \%(0)$ & $0.00 \%(0)$ & $100.0 \%(4)$ \\
\hline OCEX & $25.00 \%$ & $75.00 \%(9)$ & $0.00 \%(0)$ & $0.00 \%(0)$ & $0.00 \%(0)$ & $100.0 \%(12)$ \\
\hline
\end{tabular}

Source: personal elaboration.

Again, after applying tests Ji-squared and Correction for Continuity of Yates (p-value 1.37 and 0.39 respectively), if can be affirmed that internal auditors and members of the OCEX do not differ in their opinion to this matter. On the other hand, if we consider solely the collective of internal auditors, Kruskal-Wallis $H$ Test (p-value 0.69) reveals not significative, meaning that there are not differences in opinion to this subject between the samples for each of the five defined population strata. 
As far as the fourth hypothesis is concerned, the surveys asked the following:

Question: Should local government develop indicators of economy, efficiency and effectiveness in a compulsory manner in each service?

After data collection, the results (table 7) show the full agreement by members of the OCEX and internal auditors of municipalities of 100,000 or higher population, as well as a strong consensus in favour for the rest.

Table 7. Contingency table related to hypothesis 4

\begin{tabular}{lllllll}
\hline & Totally agree & Agree & Disagree & Totally disagree & DK/NA & Total \\
\hline $20,000-30,000$ pop. & $33.33 \%(12)$ & $58.33 \%(21)$ & $5.56 \%(2)$ & $2.78 \%(1)$ & $0.00 \%(0)$ & $100.0 \%(36)$ \\
$30,001-50,000$ pop. & $37.50 \%(6)$ & $56.25 \%(9)$ & $0.00 \%(0)$ & $0.00 \%(0)$ & $6.25 \%(1)$ & $100.0 \%(16)$ \\
$50,001-100,000$ pop. & $46.67 \%(7)$ & $46.67 \%(7)$ & $6.67 \%(1)$ & $0.00 \%(0)$ & $0.00 \%(0)$ & $100.0 \%(15)$ \\
$100,001-500,000$ pop. & $25.00 \%(2)$ & $75.00 \%(6)$ & $0.00 \%(0)$ & $0.00 \%(0)$ & $0.00 \%(0)$ & $100.0 \%(8)$ \\
$>500,000$ pop. & $50.00 \%(2)$ & $50.00 \%(2)$ & $0.00 \%(0)$ & $0.00 \%(0)$ & $0.00 \%(0)$ & $100.0 \%(4)$ \\
OCEX & $33.33 \%(4)$ & $66.67 \%(8)$ & $0.00 \%(0)$ & $0.00 \%(0)$ & $0.00 \%(0)$ & $100.0 \%(12)$ \\
\hline
\end{tabular}

Source: personal elaboration.

Also, dependency between the attributes "collective" and "opinion on this issue" is discarded, since Ji-squared p-value is 0.64 and Correction for Continuity of Yates p-value is 0. At the same time, Kruskal-Wallis H Test (p-value 0.86) indicates that there are not differences in opinion to this subject among internal auditors depending on the population covered by their local authority.

In short, the results of the surveys permit to validate the hypothesis raised and endorse the need for a system of internal control over management in public services. In order progress in this line, the next paragraphs contain our proposed scorecard of performance indicators, as a key element of the internal control system for Homecare Services.

From there, the purpose of this research is to provide a tool that serves as guidance in this task, having been elected the Homecare Service as an example of application for our proposal.

\section{Proposal for the Design of a System of Internal Control in Homecare Services}

The internal control system pursues a variety of purposes that have been referred to in the introduction. Given that the proposed system applies to a particular service, which operates within the frame of the hole local authority, our efforts are oriented to determine the contribution that has to be done from service level to allow proper development of the internal control. The next pages will show a prototype of the components that would integrate the internal control system of the service, in particular: the objectives and the operational plan, the organizational structure, the protocols and procedures and control mechanisms, primarily focused on a scorecard of performance indicators. Given the breadth of the proposal, and with the intention that the extension of this work is not excessive, only an excerpt on each of these elements will be exposed.

Before starting, it is necessary to explain that Homecare Services consist of providing support at home for the user. This usually includes psychosocial and personal care, but can also include some non-personal care such as help with cleaning, shopping, or washing clothes (HM Government, United Kingdom, 2010). In Spain, it is common that the social services department diagnoses the demand, proposes and designs the intervention, and then commissions with a care provider the execution of such intervention. This is the assumption that we will maintain in this paper. Other characteristics that might be of interest are the user's contribution to the cost of the service and its decentralized delivery through social care units, which are coordinated by the social care department.

\subsection{Design of an Internal Control System: Objectives and Operational Plan for Homecare Services}

One of the purposes of the internal control consists of monitoring the effectiveness of an institution, program, or service. The absence of a competitive market for local public social services poses the need to measure performance in relation to standards and goals, in order to improve management (Department of Health, England, 2009).

Management by objectives has been promoted by the Spanish legislation, pointing out the requirement for the targets to be quantifiable in order to measure and evaluate the progress using performance indicators (Ortiz, Navarro \& Lopez, 2006).

Therefore, it is necessary that plans and programmes express clearly the goals and objectives to be achieved, as 
well as the mechanisms for their evaluation. For example, two of the goals put forward for Homecare Services are shown next:

Objective 1: To support the development of personal capacities to achieve integration into family and community life.

Objective 2: To complement and compensate the burden of the family when, for various reasons, it presents difficulties to prevent emergency situations involving personal or social deterioration.

Based on these and other objectives, an operational plan structured like the following would be formulated (table 8).

Table 8. Operational plan for homecare service (excerpt)

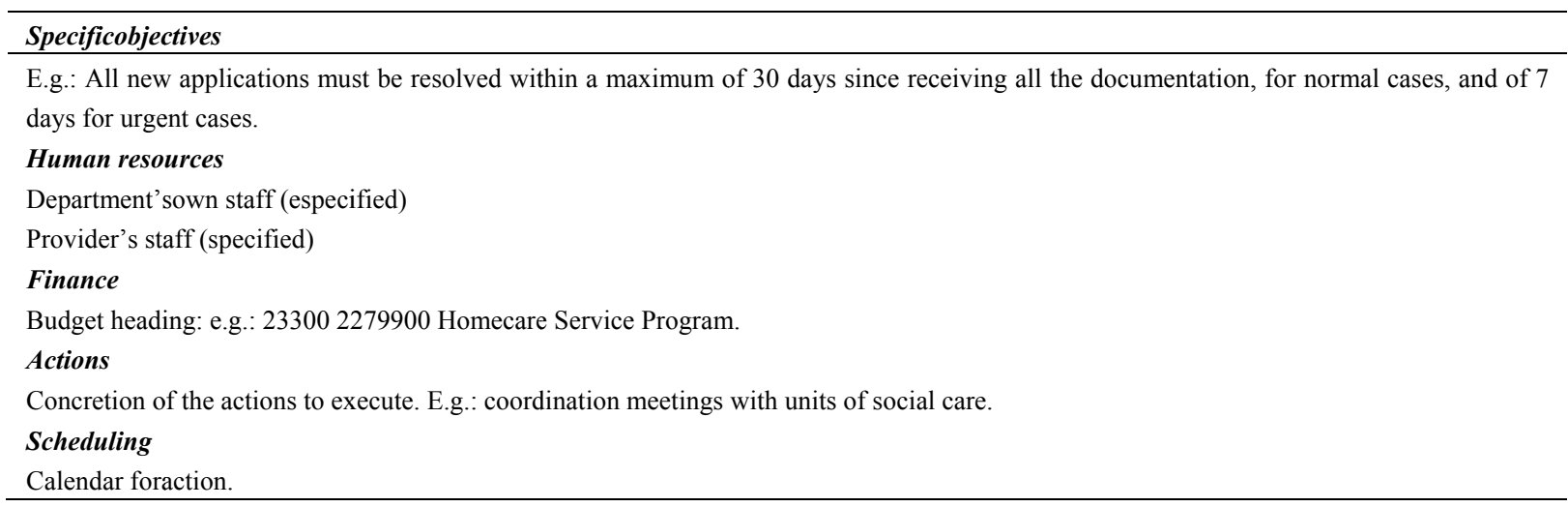

Source: personal elaboration.

\subsection{Design of an Internal Control System: Organizational Structure for Homecare Services}

The Organizational planning, represented basically by the organizational structure and the organization manual, indicates the hierarchical and functional linkages, the segregation of duties and the definition of powers, with the corresponding allocation of responsibilities at the individual level. Therefore, it constitutes an instrument for the internal control system in order to achieve their goals. A possible organizational chart for Homecare Services is shown in figure 1.

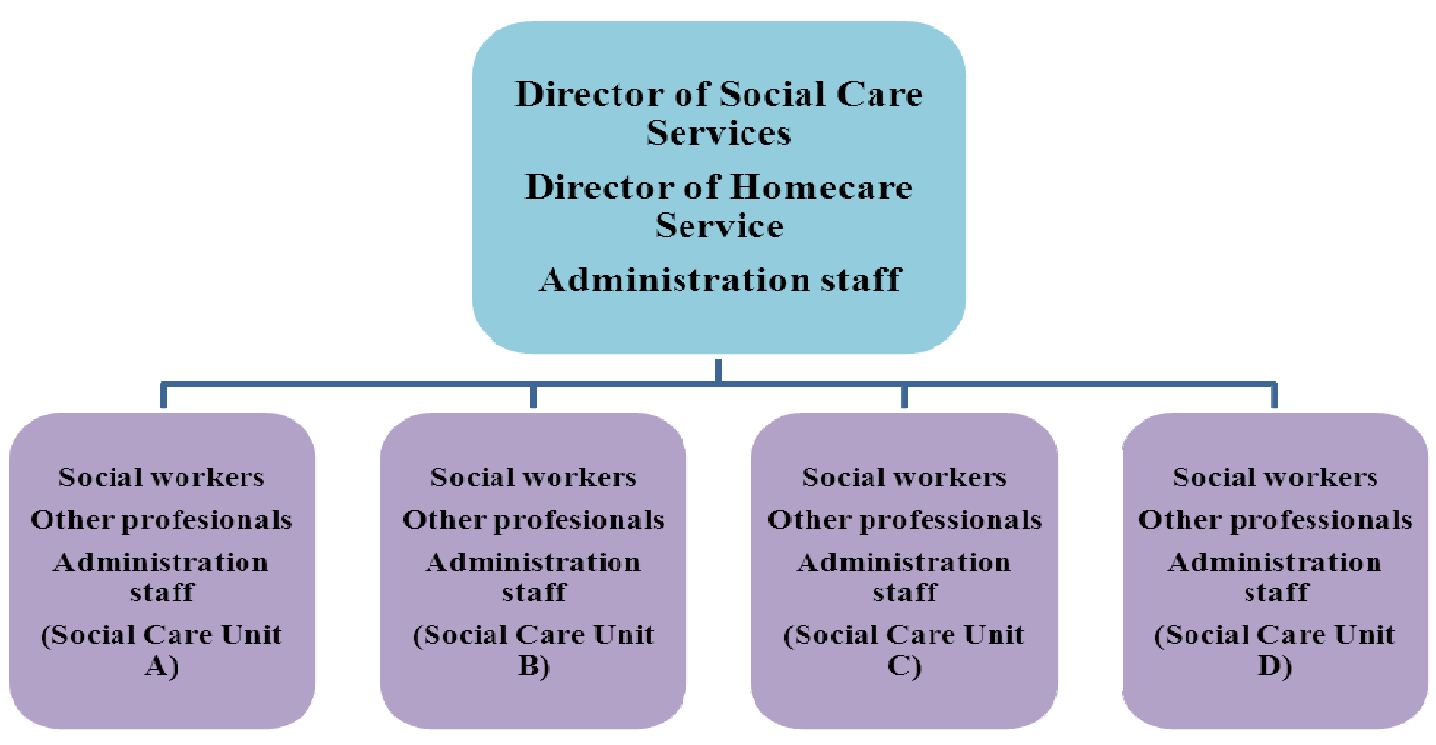

Figure 1. Organizational chart for Homecare Services

However, the chart has some limitations such as its inadequacy to express the degree of authority and responsibility of the staff, the influence among professionals of the same level and the informal structure of the organization (Jaskyte, 2004). To overcome them, it must be supplemented with an organization manual in which, 
for each post, detail is set out for the functions, tasks, rules affecting the development of the work, hierarchical relationships with other posts, operational relations information to receive and provide, related objectives, criteria of decision, authority, monitoring and assessment mechanisms of performance. Table 9 presents an excerpt of the organizational manual for the post "Director of Homecare Service".

Table 9. Organizational manual for homecare services (excerpt)

\begin{tabular}{ll}
\hline Content & Post: Director of Homecare Service \\
\hline Functions & To coordinate social workers of social care units. \\
& To manage the relationships between the Service and the provider. \\
& Institutional management of financial resources. \\
Tasks & To provide technic support to social care units, to review user records, to solve incidences, to redact \\
& memories, etc. \\
Hierarchicalrelationships & $\begin{array}{l}\text { Accountable to the Director of Social Services. } \\
\text { Social care units accountable to them with regard to this Service.. } \\
\text { provide }\end{array}$ \\
Relatedobjectives & To receive: reports and summaries on performance \\
Control mechanisms & To provide: General planning, memories of activity, financing justification. \\
\hline Source: personal elaboration. & Indicators, incentives, sanctions.
\end{tabular}

\subsection{Design of an Internal Control System: Protocols and Procedures for Homecare Services}

The definition of protocols and procedures takes as its starting point the sequence of actions involving the provision of the service which, in the case that concerns us, can be decomposed into the following methodological stages: reception of the demand, first attention, initial assessment and diagnosis, paperwork handling, start of the provision, monitoring, management of user's payment, management of the contractual relationship between the social services department and the provider, and institutional management. From the description of the previous phases, the procedures will identify activities and, for each of them, determine the people responsible for the process of authorization (A), execution (E) and control (C), as appropriate. In addition, they shall establish the documentation that should pick up the action, as well as the registry where it should be listed, for each of these basic processes. As a consequence, the procedures will contribute to create an information system useful for the purposes of the internal control (Christensen, Laegreid \& Wise, 2002).

Table 10 presents an extract from the protocols and procedures proposed for the methodological phase "Management of the contractual relationship between the social services department and the provider".

Table 10. Protocols and procedures for phase "management of the contractual relationship between the social services department and the provider"

\begin{tabular}{|c|c|c|c|c|c|}
\hline Methodological phase & Activity & Place & Process & Documentation & Register \\
\hline \multirow{8}{*}{$\begin{array}{l}\text { Management of the } \\
\text { contractual relationship } \\
\text { between the social } \\
\text { services department and } \\
\text { the provider }\end{array}$} & Activity 1: Prepare & Social & Service & & \\
\hline & and verify monthly & CareUnits & Director & & \\
\hline & list of hours by & & E: Admin.staff. & Monthly report of variations & User records data \\
\hline & social care units. & & & (hours per month) & base: \\
\hline & & & & Monthly report of hours and & Home care \\
\hline & & & & incidents & Service section \\
\hline & & & Service & & \\
\hline & & & Director & & \\
\hline
\end{tabular}

Source: personal elaboration.

\subsection{Design of an Internal Control System: Performance Indicators for Homecare Services}

The development of performance indicators constitutes one of the main components within the municipal internal control system. This applies both to verify compliance with the planned objectives and efficiency in the allocation of resources, and to establish quality standards that make possible the comparability between councils offering a service (Folz, 2004).

The development of performance indicators often requires knowledge of the cost of the activities that make up the service and the factors behind them. The access to this information involves the implementation of a Cost 
Accounting system at service level, being this still a challenge for local public managers (Note 4).

In addition, the exercise of self-assessments on management and results using indicators can also be an enabling element of cooperation between internal and external control systems. In this sense, CIPFA (2010) pointed out that, in view of the expansion of the performance reporting tools in local government, the role of external auditors is immersed in a continuous shift to the inspection of performance assessment and indicators instrumented by audited entities' internal control systems.

Also, under the last audit regime on local government put in place by the Audit Commission of England, the Comprehensive Area Assessment, recommendation was made to the audited entities to carry out self-assessments of its performance, since it would confer greater accuracy and reliability to internal and external accounting information, which would form the basis for the exercise of the external control (Local Government Association, 2010).

\subsection{Efficacy and Impact Indicators for Homecare Services}

On the assumption that the realization of the activities that make up the provision of the service, in accordance with the procedures defined, is a means for the achievement of the objectives set out for the service, it might be said that the activities themselves, once quantified, will enable the construction of indicators of effectiveness, because they can be considered as the outputs of the service. Table number 11 reflects the efficacy indicators put forward for one of the objectives laid down for the service, making a reference to the documents and registers that would supply inputs for its calculation, which have been determined through the protocols or procedures.

Table 11. Efficacy indicators for homecare services (excerpt)

\begin{tabular}{lll}
\hline Objective & Efficacy indicators & Information inputs \\
\hline $\begin{array}{l}\text { Objective 1: To support the } \\
\text { development of personal capacities to }\end{array}$ & $\begin{array}{l}\text { - Number of days since the beginning of the provision } \\
\text { until improvement is obtained / No. of users }\end{array}$ & User records data base: \\
$\begin{array}{l}\text { achieve integration into family and } \\
\text { community life. }\end{array}$ & $\begin{array}{l}\text { - Number of user records reviewed in which } \\
\text { improvement in personal abilities is detected / No. of } \\
\text { user records reviewed }\end{array}$ & $\begin{array}{l}\text { - User records } \\
\text { per monthly report of variations (hours }\end{array}$ \\
& & $\bullet$ Monthly report of hours and incidents \\
\hline
\end{tabular}

Source: personal elaboration.

This type of indicators based on the activities can be useful to gauge the fulfillment of objectives, but present limitations that recommended its consideration together with the impact indicators. It has to be taken into account, in this regard, the important weight of bureaucratic activities within the delivery of Homecare Services.

The development of impact indicators arises from the need to know the results of the activity carried out in relation to the satisfaction of the demands to be covered by the service, which should have been taken into account in the formulation of objectives. This kind of indicators would adopt the form of, for example:

The number of families-users that have seen satisfied their demand through the range of services available / total number of families-users.

Its calculation requires to poll the opinion of users and their families.

\subsection{Efficiency Indicators for Homecare Services}

Efficiency indicators are concerned with performance, productivity and cost, and entails to quantify inputs and outputs for each activity. Table 12 presents a part of our proposal of efficiency indicators for Homecare Services, related to one of the activities defined within the phase "Management of the contractual relationship between the social services department and the provider".

Table 12. Efficiency indicators for homecare services (excerpt)

\begin{tabular}{ll}
\hline ACTIVITY (output) & EFFICIENCY INDICATORS \\
\hline Activity 1: Prepare and verify monthly list & - Number of monthly reports on variations (hours per month) prepared and verified / No. \\
of hours by social care units. & administrative staff in social care units \\
& $\begin{array}{l}\text { Number of monthly reports on variations (hours per month) prepared and verified/total cost } \\
\text { of the activity. } \\
\text { - Time devoted to the activity/ No. of monthly reports on variations (hours per month) } \\
\text { prepared and verified. }\end{array}$ \\
\hline
\end{tabular}

Source: personal elaboration. 


\subsection{Economy Indicators for Homecare Services}

The analysis of the economy is concerned with the costs and conditions in which procurement and contracts take place. The internal control of the economy must be informed from the direction of Homecare Services through indicators and reports which include needs forecasting and data on costs, among others, in order to facilitate a more rational acquisition of factors. Our proposal of indicators of economy is broken down into two groups, based on budgetary and analytical information:

a)A first group referred to the cost incurred per physical unit of input, such as:

Personnel costs attributable to the service / number of hours dedicated by the staff to the service.

b) A second group referred to the cost incurred per user or inhabitant, for example:

Personnel costs attributable to the service / No. users

These two groups of indicators have been developed in our proposal for the rest of inputs and should be prepared by each social care unit.

In addition, together with the means property of the social care department, the delivery of Homecare Services involves commissioning a number of hours with the provider. To this regard, the negotiation of the contract with the company should follow economy criteria, being applicable the comments bellow:

Prior to the negotiations, the selection process should promote competition between private and social providers. It would be interesting that the social care department promoted market development.

It must start from the knowledge of the real cost of the activities to be commissioned, as well as consider the hourly rate paid by other local authorities where provision is comparable.

\section{Conclusions}

Organizations need internal control in order to preserve their interests and objectives. In the public sphere, these mechanisms are even more necessary due to the coexistence of political and technical agents in the functions of planning and management, to the duty of accountability and, above all, to the citizens demand of law compliance and value for money in public services delivery.

Proper public management is not possible without the existence of internal control mechanisms that ensure information reliability for decision making. Its implementation implies overcoming certain weaknesses detected in the Spanish local government internal control function, led by the internal auditor or interventor. In particular, the control is focused on legality and probity, at the expense of value for money, and little cooperation is observed between internal and external audit, especially in the field of economy, efficiency and efficacy.

Based on this scenario, the presented paper shows the existence of consensus among those responsible for the control over the Spanish local government, both internal and external, on the need of designing and implementing internal control mechanisms that generate reliable and useful information on performance and results. It also highlights the advantages of developing self-assessments and performance indicators and the demand for clearing up the internal auditors responsibilities in these areas.

Homecare Services are taken as an example for the design of and internal control system which contributes to solve some of the problems identified. The proposal intends to provide a scheme for control at service level, which should embed in a bigger internal control system for the whole Authority. Its integral parts range from a definition of the service objectives, the identification of phases and activities, and the quantifications of inputs and outputs, to the construction of performance indicators that permit the exercise of control.

The system put forward intends to become a key instrument for undertaking service self-assessments, which could be used as a basis for the accomplishment of value for money audits at both internal and external level. This idea is one of the future lines of research of the work submitted.

\section{References}

Antonnen, A., \& Sipila, J. (1996). European social care services: is it possible to identify models? Journal of European Social Policy, 6(2), 87-100. http://dx.doi.org/10.1177/095892879600600201

Asociación Estatal de Directores y Gerentes de Servicios Sociales. (2007). Las nuevas Leyes de Servicios Sociales: criterios para valorar su elaboración o sus contenidos. Retrieved from http://www.directoressociales.com

Barquero, M. (2008). El control interno en los trabajos de fiscalización. Auditoría Pública, 47, 47-56.

Biosca, F. J. (2010). La apariencia de control en la administración local por los habilitados estatales. Auditoría 
Pública, 52, 71-78.

Birkett, W. P. (1988). Concepts of Accountability. Sydney: University of New South Wales, School of Accounting.

Boyne, G., Gould-Williams, J., Law, J., \& Walker, R. (2002). Plans, Performance Information and Accountability: The case of best value. PublicAdministration, 80(4), 691-710. http://dx.doi.org/10.1111/1467-9299.00324

Brugue, Q. (1996). La dimensión democrática de la nueva gestión pública. Gestión y Análisis de Políticas Públicas, $5(6), 45-58$.

Byars, L. L. (1984). Strategic Management. Planning and Implementation, Concept and Cases. New York, NY: Harper\&Row.

Casado, D., \& Fantova, F. (2007). Perfeccionamiento de los Servicios Sociales en España. Informe con ocasión de la Ley sobre autonomía y dependencia. Madrid: FOESSA y Cáritas Española Editores.

Christensen, M., \& Yoshimi, H. (2003). Public sector performance reporting. Government Auditing Review, 10, 72-83.

Christensen, T., Laegreid, P., \& Wise, L. R. (2002). Transforming administrative policy. Public Administration, 80(1), 153-178. http://dx.doi.org/10.1111/1467-9299.00298

Cofffey, A., \& Atkinson, P. (2005). Encontrar el sentido a los datos cualitativos. Variedades de datos y Variedades de Análisis. Alicante, Universidad de Alicante: MG.

Conferencia de Presidentes de los Órganos Autonómicos de Control Externo. (2006). Retrieved from http://www.eurorai.org/eurorai/eurorai_es.nsf/documento/informes_nacionales $/ \$$ file/Informe $\% 20$ nacional $\%$ 20Espa\%C3\%B1a-versi\%C3\%B3n\%202012.pdf

Cooper, W., \& Lybrand, W. (1997). Los nuevos conceptos del control interno (Informe COSO). Madrid: Díaz de Santos, S. A.

Department of Health, England. (2009). Use of Resources in Adult Social Care: A guide for local authorities. London: DH.

Díez, J. (1999). Envejecimiento y políticas hacia los mayores en la Unión Europea. In Múñoz, S., García, J. L. \& González, L. (Eds.), Las estructuras del Bienestar en Europa. Madrid: CIVITAS.

El Defensor del pueblo del País Vasco. (2010). La situación de los Servicios Sociales de Base en la Comunidad $\begin{array}{lllll}\text { Autónoma } & \text { del } & \text { País } & \text { Vasco. } & \text { Retrieved }\end{array}$ http://www.ararteko.net/RecursosWeb/DOCUMENTOS/1/1_1941_3.pdf

Esping-Andersen, G. (1990). The Three Worlds of Welfare Capitalism. Princenton: Princenton University Press.

Fantova, F. (2008). Sistemas públicos de servicios sociales: nuevas necesidades, nuevas respuestas. Bilbao: Ed. Mensajero.

Federación Española de Municipios y Provincias (FEMP)-Ministerio de Administraciones Públicas. (2009). Propuesta para la configuración de un nuevo modelo de servicios sociales municipales. Madrid: FEMP.

Federación Española de Municipios y Provincias (FEMP)- Ministerio de Administraciones Públicas (España). (2010). Manual de Procedimiento para la Implantación de un Sistema de Costes en la Administración Local (MAPISCAL). Madrid: FEMP.

Fernández, J. M., \& Rodríguez, A. (2008). Modernización de la gestión pública. Necesidad, incidencias, límites y críticas. PECUNIA, Revista de la Facultad de Ciencias Económicas y Empresariales de la Universidad de León, 6, 75-105.

Folz, D. H. (2004). Service quality and benchmarking. Public Administration Review, 64(2), 209-220. $\mathrm{http}: / / \mathrm{dx}$.doi.org/10.1111/j.1540-6210.2004.00362.x

Garau, J. (2005). Guía para la gestión de la calidad de los procesos de servicios sociales. Barcelona: Ed. INTRESS.

Garcia Herrero, G. (2005). Ideas, argumentos y propuestas sobre los servicios sociales, la autonomía personal y la protección a las personas en situación de dependencia. Trabajo Social Hoy, 2, 17-66.

García, I. (2007). La nueva gestión pública. Evolución y tendencias. Presupuesto y Gasto público, 47, 38-40.

García, T. (2005). Etapas del proceso investigador: Población y Muestra. Madrid: Almendralejo. 
González, J. (2008). Manual de Presupuestos y Contabilidad de las Corporaciones Locales. (7th ed.). Madrid: Wolters Kluwer.

Gummer, B. (1988). Competing Perspectives in the Concept of "Effectiveness" in the Analysis of Social Services. Administration in Social Work, 11, 257-270. http://dx.doi.org/10.1300/J147v11n03_24

Helgason, S. (1997). Toward Performance-Based Accountability. Paris: Organisation for Economic Co-operation and Development.

Hesse-Biber, S. N., \& Laeavy, P. (2006). The practice of qualitative research. Thousand Oaks: SAGE.

HM Government (United Kingdom). (2010). Building the National Care Service. London: DH.

Hughes, O. (1994). Public Management and Administration. London: Macmillan Press.

Instituto de Contabilidad y Auditoría de Cuentas (España). (1991). NormasTécnicas de Auditoría Españolas. Madrid: ICAC.

International Organization of Supreme Audit Institution (INTOSAI). (2004). Guidelines for Internal Control Standards for the Public Sector. Retrieved from http://www.issai.org/media(574,1033)/intosai_gov_9100_e.pdf

Jaskyte, K. (2004). Transformational leadership, organizational culture and innovativeness in nonprofit organizations. Nonprofit Management and Leadership, 15(2), 153-168. http://dx.doi.org/10.1002/nml.59

Kelley DSW, J. B. (1984). The Spanish Municipal Social Service Center as the Basic Provider of Services. Administration in Social Work, 8(4), 93-93. http://dx.doi.org/10.1300/J147v08n04_08

Kravchuk, R., \& Shack, R. W. (1996). Designing Effective Performance Measurement Systems Under the Government Performance Results Act of 1993. Public Administration Review, 56(4), 348-58. http://dx.doi.org/10.2307/976376

Lazo Victoria, X. (2008). El control interno del gasto público estatal. Madrid: Tecnos.

Ley 39/2006, de 14 de diciembre, de Promoción de la Autonomía Personal y Atención a las personas en situación de dependencia. Retrieved from http://www.boe.es/boe/dias/2006/12/15/pdfs/A44142-44156.pdf

Ley 7/1985, de 2 de abril, Reguladora de las Bases del Régimen Local. Retrieved from http://www.minhap.gob.es/Documentacion/Publico/NormativaDoctrina/FinanciacionTerritorial/Financiacio n\%20Local/Ley\%207_1985\%20titulos\%208y10.pdf

Local Government Association (England). (2010). CAA evaluation: a sector perspective on year 1. London: LGA.

Ministerio de Trabajo y Seguridad Social, España. (1988). Plan Concertado de Prestaciones Básicas de Servicios Sociales en las Corporaciones Locales. Madrid: MTSS.

Morse, J. M. (2005). Emerger de los datos. Los procesos cognitivos del análisis en la investigación cualitativa. In J. M. Morse (Ed.), Asuntos críticos en los métodos de investigación cualitativa (pp. 29-52). Alicante: Universidad de Alicante.

Navarro, A., Ortiz, D., \& López, A. (2008). Identifying barriers to the application of standardized performance indicators in local government. Public Management Review, 10(2), 241-262. http://dx.doi.org/10.1080/14719030801928706

Ortiz, D., Navarro, A., \& López, A. (2006). Consensus among Public Managers as Strategy for Standardization of Performance Indicators. International Public Management Journal, 9(4), 371-398. http://dx.doi.org/10.1080/10967490601077129

Pallot, J. (2001). Transparency in local government: Antipodean initiatives. European Accounting Review, 10(3), 645-660.

Pérez López, C. (2003). Técnicas Estadísticas con SPSS. Madrid: Prentice Hall.

Real Decreto Legislativo 2/2004 de 5 de marzo, por el que se aprueba el Texto Refundido de la Ley Reguladora de las Haciendas Locales (TRLRHL).

Real Decreto Ley 19/2012, de 25 de mayo por el que se modifica el Texto Refundido de la Ley Reguladora de las Haciendas Locales de 2004.

Rubenstein, R., Schwartz, A., \& Steifel, L. (2003). Better Than Raw: A guide to measuring organisational performance with adjusted performance measures. Public Administration, 63(5), 607-14. http://dx.doi.org/10.1111/1540-6210.00323 
Santos, J., Muñoz, A., Juez, P., \& Guzmán, L. (1999). Diseño y tratamiento estadístico de encuestas para estudios de mercado. Madrid: Editorial Centro de Estudios Ramón Areces, S.A.

Setién, M. L., \& Sacanell, E. (2003). La calidad en los servicios sociales. Valencia: Ed. Tiran lo Blanc.

Subirats Humet, J. (2007). Los servicios sociales de atención primaria ante el cambio social. Madrid: Ministerio de Trabajo y Asuntos Sociales.

Torres, L. (2002). La Auditoría Operativa: un instrumento para la mejora de la Gestión Pública. Madrid: AECA.

Torres, L., Pina, V., \& Yetano, A. (2011). Performance Measurement in Spanish Local Governments. A Cross-Case Comparison Study. Public Administration, 89(3), 1081-1109. http://dx.doi.org/10.1111/j.1467-9299.2011.01919.x

Vicéns, J., \& Medina, E. (2005). Análisis de datos cualitativos. Retrieved from http://www.uam.es/personal_pdi/economicas/eva/pdf/tab_conting.pdf

Viñas, J. P. (2002). Patología y terapia de las Cuentas Públicas Territoriales. El Consultor de los Ayuntamientos y de los Juzgados, 8(1), 1371.

Viñas, J. P. (2003). El control interno en las Entidades Locales. Limitaciones legales y desajustes funcionales. Un estudio comparado. El Consultor de los Ayuntamientos y de los Juzgados, 14(2), 2498.

Zafirovski, M. (2001). Administration and Society: Beyond Public Choice? Public Administration, 79(3), 665-688. http://dx.doi.org/10.1111/1467-9299.00274

Zafra, J. L., López, A., \& Hernández, A. (2009). Developing an alert system for local governments in financial crisis. Public Money \& Management, 29(3), 175-181. http://dx.doi.org/10.1080/09540960902891731

\section{Notes}

Note 1. Other research related to this Service might be consulted in Kelley DSW (1984) and Gummer (1988).

Note 2. About this subject, it can be consulted Zafra, López\& Hernández (2009).

Note 3. Independency has not been discarded in any of the questions that will be shown in this paper, which implies association coefficients have not been applied.

Note 4. It is worth highlighting the contribution of some initiatives such as the Manual of procedures for the implementation of a Cost Accounting system for Local Management (MAPISCAL) (FEMP, 2010), which will be soon complemented by the publication of the sectorial guide for social care services, among others. 